\title{
Recognition and Accumulation
}

\author{
Tarik Kochi*
}

\begin{abstract}
Within political theory the concept of recognition has been generally drawn upon to develop a particular form of ethical theory. The concept has been deployed in debates over culture, feminism, multiculturalism, individual and group rights, and as a means of conceptualising colonialism. A less dominant contemporary line of inquiry is the use of the concept of recognition to think through modes of pre-capitalist and capitalist accumulation.

Much of the early philosophical radicalism contained within the concept of recognition has been lost via its subsumption within liberal political theory. Against such a liberal 'flattening-out' of recognition this article builds an alternative interpretation which focusses upon the relationship between recognition and accumulation. This is done by way of examining how questions of economic power and accumulation were central G.W.F. Hegel's theory of recognition.
\end{abstract}

In this light, this paper develops an understanding of recognition as a 'hinge concept' one which links economic relations, the juridical form, moral claims and political struggle. This is not to portray recognition in any economically determinist sense. Rather, by focussing upon its antagonistic basis, as struggle, a concept of recognition gives us a useful way of thinking about both historical and contemporary modes of global capitalist accumulation.

\footnotetext{
* Senior Lecturer, School of Law, Politics and Sociology, University of Sussex. This is the final author's version of the published work cited as: Kochi, T. "Recognition and Accumulation" in Hayden, P. \& Schick, K. (eds.) Recognition and Global Politics: Critical Encounters Between State and World, (Manchester: Manchester University Press, 2016), pp. 85-98.
} 


\section{Introduction}

The latter years of the $20^{\text {th }}$ century saw the emergence of a number of very interesting reinterpretations of G.W.F. Hegel's moral and political philosophy in which the concept of 'recognition' (Anerkennung) was given pride of place. Scholars such as Ludwig Siep, Gillian Rose, Axel Honneth, Robert R. Williams, Charles Taylor and Robert Pippin drew attention to the primary role that recognition played within Hegel's philosophical system. In differing ways each developed dynamic interpretations of Hegel's philosophy, reopened and reenergised by the struggles, play and follies of recognition and misrecognition operating on and across a variety of differing registers.

One result of this new line of Hegel-interpretation has been the take-up of a concept of recognition as something of a stand-alone theory within political thought more generally. In particular the very popular philosophical exchange around the concept of recognition between Axel Honneth and Nancy Fraser (Fraser and Honneth 2003) has sparked a small academic discourse of recognition theory and its application to identity politics, questions of moral and political rights and issues of global justice. While aspects of recognition theory have been adopted in interesting ways within feminism and post-colonial studies, perhaps the predominant branch has been utilised by liberal political theory with rather less exciting results.

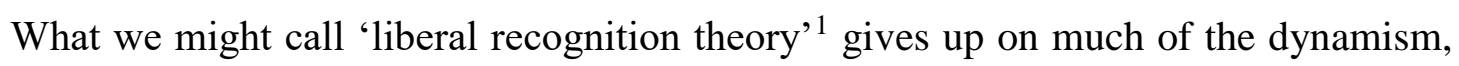
radicalism and philosophical potential that was articulated by earlier Hegel-recognition scholarship and instead, what gets presented is generally a reduction of the concept of recognition to a set of liberal rights and identity questions. In this discourse, the concept of

\footnotetext{
${ }^{1}$ See for example: McBride, 2013.
} 
recognition is 'flattened-out', beaten almost lifeless, and becomes merely a functional mechanism used to better organise liberal politics. In other words, the concept of recognition is reduced to strategy within a language game played by liberal political theorists whose global philosophical horizons extend little further than the texts of John Rawls and Jürgen Habermas.

Alongside liberal recognition theory resides a social-democratic theory developed by Nancy Fraser which draws conceptual and political distinctions between claims for economic redistribution and a politics of recognition. While her position seeks to integrate these into a broader theory of social justice, it relies upon a somewhat over-determined and erroneous separation between modes of status subordination and economic subordination. Fraser's account overlooks the historical ways in which a politics of recognition always involves claims over economic inequality, injustice and redistribution. To miss this connection is to ignore something crucial about the nature of recognition and its connection to any radical, transformative political project.

What this paper seeks to present is an interpretation of the concept of recognition which undercuts these versions of liberal and social-democratic recognition theory, and instead draws attention to the important role of thinking about recognition in terms of political economy and struggles over economic justice. Drawing upon a reading of the concept of recognition in the philosophy of Hegel, I will show that there are resources within a theory of recognition which point to important questions of international political theory often ignored by liberal political theory. In what follows I will develop an understanding of recognition as a 'hinge concept' one which links economic relations, the juridical form, moral claims and political struggle. This is not to portray recognition in any economically determinist sense. Rather, by focussing upon its antagonistic basis, as struggle, a concept of recognition gives us a useful way of thinking about both historical and contemporary modes of global capitalist accumulation and struggles over economic justice. 


\section{Lords and Bondsmen Made Free}

Hegel's most infamous passage on recognition, that which gets all of the attention, that which brings Johann Fichte's concept of recognition into the light, radicalises it, transforms it, is presented in the second section of the Phenomenology of Spirit (1807). There are many different and varied interpretations of this section, some perhaps more convincing than others. What I want to emphasise in this interpretation is the link between political, economic and juridical forms that are presented in the relation of Herrschaft and Knechtschaft, sometimes translated as the relationship between 'lord and bondsman', or between 'master and slave'. My argument is that we need to take seriously Hegel's presentation of the relation between lord and bondsman as a something of a 'hinge concept'. As a hinge concept he is introducing an idea which has trans-historical significance at a very abstract level, but on the other hand, contains alternative modes of concrete meaning within differing historical and cultural epochs. This hinge concept links the political, juridical, and moral to the economic order.

For example, we could think of Hegel's account of the relation between master and slave as being situated within the ancient economies Greece and Rome. This makes some sense given that the section on stoicism and scepticism follows the section on master and slave. In referring to the ancient economy Hegel is presenting a very personal relation of power and domination of one body over another. In contemporary language, this is something of a 'biopolitical' relation in which the master controls and regulates not merely the life of another, but life in general, the plural, often indeterminate lives of a number of slaves.

Such an inter-personal, or inter-subjective power relation is a political relationship, it is a constitutive part and outcome of a political process of the Greek polity or Roman republic in which a sphere of freedom is attached to citizenship and a sphere of unfreedom to slavery - 
those who are predominantly non-citizens, captured in battle and whose coerced labour materially sustains the political relation of the ancient republic. ${ }^{2}$ In this sense the ancient republic is made possible through a form of political exclusion and economic inclusion of slaves (as well as of women and foreigners). The labour of the slave opens the political space of citizenship, it allows the citizen of the ancient republic the leisure time to actively participate in a plural, agonistic political process. Hence the excluded, the written-out, those outside the order, are constitutive of its inside, the included, the celebrated. ${ }^{3}$

Here the relationship of ancient slavery is a hinge concept which links very clearly the interdependent relationship between politics and economic production. Ancient republican citizenship, civic participation in public deliberation, policy-making and in judicial decisions are reliant upon an economic form of labour and production in which the coercive nature of ancient slavery plays an important role. That is, the political realm of the ancient republic cannot be disconnected from the economic relation of ancient slavery. This is not to argue a dogmatic and defunct position of base-superstructure, but merely to state a rather common sense materialist position, that the political constitution cannot be disconnected from the economic constitution.

We can read Hegel's account of the relation between master and slave as a story which emphasises an important linkage in which the ancient political mode of understanding and selfunderstanding (i.e. 'self-consciousness') is one of freedom of the citizen of the republic set openly against the unfreedom of the slave. Self-consciousness thus is shaped by an understanding derived from the ancient republican political mode and also from the ancient economy which was heavily reliant upon slavery. This form of self-understanding then drew upon, or was mediated through, the legal categories of citizenship, slavery, property ownership

\footnotetext{
${ }^{2}$ My account of the ancient economy is a very inexact gloss. For clearer accounts, see generally: Finlay 1999; Brunt 1971; Anderson 1996; Forrest 1966; Mann 1986.

${ }^{3}$ On the constitutive role of exclusion generally see: Nancy 2000.
} 
(in which the slave is a thing), and a set of normative or moral beliefs governing differing forms of inter-personal relationships whereby such legal 'status' played a predominant role.

Such a relation was also 'international' or inter-republic if we think then of the important role that war played in ancient state-formation and in the deriving of the economic resource of slavery. The ancient republic's economic mode of slave production was reliant upon a constant process of international conflict in which enemy non-citizens, via capture in war, were drawn in as the included-excluded part of the ancient republic - the non-citizenforeigner-barbarian whose labour sustains the ancient republic and who makes a republican politics of liberty and agonistic deliberation possible. The 'struggle for recognition' contains then, from the beginning, an 'international' dimension, as one outcome of ancient war was the possible humiliation of a formerly free citizen-soldier being captured and then sold into slavery. In this sense, the struggle to the death is the choice of a form of honourable death for the republic, or the clinging onto life then lived through the unfreedom and domination as a slave. This life, a life of labour, of drudgery, is the life that makes the freedom of the other (the slaveowner, the rival ancient republic or empire) possible. In this respect the concept of recognition designates a division of labour in which coerced, economic slave production is linked to the free political sphere of the republican form. In this the political and economic (together with the juridical and ethical) are co-constitutive, each one is dependent upon the other, freedom and unfreedom inter-dependent.

Thought of in this sense, recognition involves the free mutual recognition between some as citizens within the ancient republic, each holding and affirming in each other a shared sense of social being - that of having their existence and identity as mediated and realised through each other and through their collective political form in the sense celebrated by Aristotle's Politics (350 BCE). That is, recognition between free citizens is an ethical relation whereby through the self-identification of self-other as common, some form of 'good life' (eudemonia) 
may be realised. For Hegel, this mode of mutual recognition situated in ancient republics is not natural, but historical and political and must be won. Further, it contains within in it a moment of exclusion and the refusal to recognise a very large number of human beings who are reduced to a level of limited recognition, dominated and forced into servitude. This relation of recognition and misrecognition is violent, it involves struggle and war stretching between and across communities.

Recognition as a hinge concept links the polis with the oikos, it links the sphere of free political citizenship with the economic sphere of slave labour and accumulation. Hegel's insight is important here, recognition involves deliberation, it is the back and forward of argument and ideas, it is a linguistic tension and as such emphasises the agonism of ancient republican politics in a way that has been subsequently inherited and celebrated in the $20^{\text {th }}$ century political theories of Hannah Arendt and Jürgen Habermas. Yet, Hegel's concept of recognition explicitly links the agonism of the polis to the antagonism of political struggle, inter-communal war, open violence, domination and the coercive economic relation of slave labour. In both Arendt and Habermas, as in much liberal political theory, this link is generally underemphasised or ignored. Hegel, like Niccolò Machiavelli before him, and like Carl Schmitt and Walter Benjamin after, was acutely aware of the role of violence in constituting and sustaining forms of political community. On this view, there is an uneasy continuum between the polite deliberation and disagreement within forums, senates and parliaments, and the fighting and killing that brings these into being and sustains them internally against opposition and against rival communities and empires.

This understanding of recognition makes clear the link between free political deliberation amongst citizens and a coercive economic mode of production. The political, the sphere of freedom (citizenship, deliberation, plurality) is bound to the economic, the sphere of unfreedom (slavery, domination). What mediates the two is force, coercion, which at times is 
open violence and war and which is also the operation of political/economic struggle over freedom, over economic justice and the control and distribution of surplus.

If we were to think of other historical forms of political domination and struggle which Hegel's account touches upon, or could be seen to be drawing upon, then the idea of thinking about recognition as a hinge-concept between the political and economic constitutions holds further weight. In each, the idea of struggle plays an important role. One might think of the relationship between lord and bondsman as describing a set of feudal relations and the struggle for recognition being quite openly a conflict over political rights and control of surplus carried out between the noble class of the manor and their serfs, bonded peasants and tenant farmers. Recognition in this sense might be thought more openly as modes of political and economic domination, as class struggle, in the sense expressed by Marx in the opening of the Communist Manifesto (1848), and of that described in differing ways by Marxist historians such as Rodney Hilton and Robert Brenner. Another way may be to think of recognition in relation to modern colonialism and slavery, and in particular, with regard to the Haitian slave revolt and constitution of a Haitian republic following the interpretation of Susan Buck-Morss. A third, would be to think of recognition of a hinge concept linking the political and economic in relation to struggle for recognition taking place via the French Revolution and Terror, as celebrated in the interpretation of Hegel offered by Kojève.

\section{Recognition in the Capitalist Economy}

Hegel's account of the modern market or 'capitalist' economy can be found in the Philosophy of Right (1820) and primarily in the section on 'Civil Society' (die bürgerliche Gesellschaft), which sandwiched between the institutions of the Family and the State, make up the concrete content of 'Ethical Life' (Sittlichkeit) within the modern, Western European world. Hegel's account shows quite a heavy influence of Adam Smith in sketching an account of political 
economy in which individual property owners operate within a realm of exchange and wagelabour and whose individual desires and needs are mediated through market mechanisms which allow a thin level of universality and which in turn help to influence an infinite set of consumer wants and desires (Hegel 1991: §182-7). ${ }^{4}$

The relationship between differing consumers and producers mediated by exchange in the market is for Hegel a particular historical instantiation of the concept recognition. This mode of recognition is however different in form and content to the mode of recognition that takes place in the relationship of love in the family, and is different again to the mode of recognition that may take place when citizens identify and comprehend their social being in and through the political relationship of the state. In this account, there is a clearer distinction, a separation between the spheres of family life, the capitalist economy, and the political realm. Unlike the ancient economy, in the modern market or capitalist economy the individual, existing under conditions of modern freedom, can be both (in differing degrees) a citizen and a worker.

In this respect Hegel's account describes a (somewhat idealised) economic and political situation in Western Europe, in which a degree of basic individual liberty is necessary for wage labour and the freedom of exchange within the market. For Hegel, recognition within the market economy is two-fold. It involves a degree of recognition of the formal legal personality of individuals and property owners who interact and affirm each other through market-based exchange (Hegel 1991: §191, 192). Yet, the formality of this market-based interaction means

\footnotetext{
${ }^{4}$ On the influence of classical political economy on Hegel's thought see more generally: Riedel 1984; Ritter 1982; Avineri 1972; Pocock 2003. Hegel echoes a theme about the economic productive and utilitarian nature of commercial self-interest that runs from Grotius to Hobbes to Mandeville to Locke and is given its clearest expression by Adam Smith. Hegel argues:

In this dependence and reciprocity of work and the satisfaction of needs, subjective selfishness turns into a contribution towards the satisfaction of the needs of everyone else. By a dialectical movement, the particular is mediated by the universal so that each individual, in earning, producing and enjoying on his own account, thereby earns and produces for the enjoyment of others. (Hegel 1991:§ 199)
} 
that the degree of freedom and self-other affirmation is limited. Freedom via market-based recognition is limited to levels of wealth and resources set against the infinite social creation of desires and demands (Hegel 1991: §195).

Hegel's consideration of the problems of poverty and alienation is more developed and nuanced than that of Adam Smith (and Adam Ferguson) before him and we can interpret the concept of recognition as being turned towards a wider consideration of these questions within a market or capitalist economy. One consequence of a market-based society of producers and consumers whose inter-subjective social relationships are mediated via private property rights, contracts and market exchange, and in which labour takes place on the basis of ever-increasing division of labour, is the atomisation of society. This involves the tearing up of old social bonds, forms of cultural attachment and the destruction of the protective modes of group-identity within families. Recognition then is the relationship of alienated individuals acknowledging and affirming the aspects of their alienated selves - a formal and limited relation of intersubjective affirmation (Hegel, 1991: §238, 241).

One further consequence of the inequalities of market societies is for Hegel the problem of poverty, of which it is worth quoting a few passages:

Not only arbitrariness, however, but also contingent physical factors and circumstances based on external conditions (see $\S 200$ ) may reduce individuals to poverty. In this condition, they are left with the needs of civil society and yet - since society has at the same time taken from them the natural means of acquisition (see $\S 217$ ), and also dissolves [aufhebt] the bond of the family in its wider sense as a kinship group (see $\S$ 181) - they are more or less deprived of all the advantages of society, such as the ability to acquire skills and education in general, as well as the administration of justice, healthcare, and often even the consolation of religion...(Hegel 1991: §241)

The existence of poverty, and the active process of impoverishment of parts of a market society stem, for Hegel, from a combination of 'natural' inequalities and from inequalities of capital (Hegel 1991: §200). As opposed to the ancient economy in which the slave was excluded from full recognition of its individuality via open force and coercion, in modern 
market or capitalist economies individuals are formally recognised as free individuals and potential property owners, but are excluded through the actual conditions of material inequality. It is an economic relation of impoverishment which denies individuals mutual recognition as 'free' individuals within market society. On Hegel's account, one consequence of modern impoverishment is the emergence of a class in society, a 'rabble' (Pöbel), who feel their conditions of social inequality as a 'wrong' inflicted upon them. Hegel argues:

When a large mass of people sinks below the level of a certain standard of living which automatically regulates itself at the level necessary for a member of society in question - that feeling of right, integrity [Rechtlichkeit], and honour which comes from supporting oneself by one's own activity and work is lost. This leads to the creation of a rabble, which in turn makes it much easier for disproportionate wealth to be concentrated in a few hands. (Hegel 1991: §244)

In the Addition to this section, Hegel states:

Poverty does not reduce people to a rabble; a rabble is created only by the disposition associated with poverty, by inward rebellion against the rich, against society, against government etc. (Hegel 1991: §244)

In editing the H.B. Nisbet English translation of the Philosophy of Right, Allan Wood has attached to this section in the footnotes, material from Hegel's Lectures of 1819-20. In these Hegel states:

The poor are subject to yet another division, a division of emotion [Gemüt] between them and civil society. The poor man feels excluded and mocked by everyone, and this necessarily gives rise to an inner indignation. He is conscious of himself as an infinite, free being, and thus arises the demand that his external existences should correspond to this consciousness. In civil society it is not only natural distress against which the poor man has to struggle. The poor man is opposed not only by nature, but also by my will. The poor man feels as if he were related to an arbitrary will, to human contingency, and in the last analysis what makes him indignant is that he is put into this state of division through arbitrary will. Self-consciousness appears driven to the point where it no longer has any rights, where freedom has no existence. In this position, where the existence of freedom becomes something wholly contingent, inner indignation is necessary. Because the individual's freedom has no existence, the recognition of universal freedom disappears. From this condition arises the shamelessness that we find in the rabble...

On the one hand, poverty is the ground of the rabble-mentality, the non-recognition of right; on the other hand, the rabble disposition also appears where there is wealth. The 
rich man thinks that he can buy anything, because he knows himself as the power of the particularity of self-consciousness. Thus wealth can lead to the same mockery and shamelessness that we find in the poor rabble. The disposition of master over the slave is the same as that of the slave ... these two sides, poverty and wealth, thus constitute the corruption of civil society. (Hegel 1991: pp. 453-4)

These passages are quite telling, they lead in differing ways towards Nietzsche's category of 'ressentiment', and towards Marx's notion of the development of the notions of 'class consciousness' and 'class struggle'. It is in these passages that the importance of thinking about 'recognition' as a hinge-concept arises quite clearly. It is the conditions of impoverishment and the sense of the 'wrong' done to the poor which leads to the feeling of being not fully recognised by society and of directing anger back against the rich, against society, against government. Recognition here refers to a mode of self-reflection, selfconsciousness in which the poor attempt to comprehend the reasons for their impoverishment, upon which they come to reflect upon the causes of their inequality. It is the sharp and contradictory split between the idea of modern market or capitalist society in which the individual is given the ideal of freedom, of autonomy, of liberty, and, the material reality of being consistently denied this through economic inequality - of being reduced to some form of economic servitude.

Hegel's response is closer to Adam Smith than to Marx. It is towards the provision of public authorities to attempt to alleviate questions of health, education and poverty (Hegel 1991 §245). Further, the political realm of the modern state is intended to provide some kind of reconciliation to bring all citizens back into the fold, to give them some access to shared mutual recognition, universality and common identity. The story of Marx's critique of this idealisation is well-known, as is his turning of the critical analysis of political economy via alienation, commodification and impoverishment into a wider societal 'struggle for recognition' in which wage-labouring slaves (proletariat) attempt to overcome, via political organisation and force, 
an economic system and class rule within modern capitalism. ${ }^{5}$ This position puts Marx's account of the master-slave relation closer to the younger Hegel of the Phenomenology of Spirit, closer to modern and ancient republican theories of class conflict and revolution of Machiavelli and the Gracchi, and closer to the slave uprisings of Spartacus and of Haiti.

Still, regardless of which direction these set of struggles sail off towards what remains clear is the work recognition does as a hinge-concept, linking economic relations to political conflict and linking these also to juridical forms and moral conceptions of value, worth, dignity and entitlement. Recognition in this sense is not merely the apportionment of rights within a liberal market society, it is the active process in which the process of alienation, commodification, inequality and class power within modern capitalism leads to the formal recognition in political and juridical senses and non-recognition and exclusion of those who are impoverished. The moral indignity of this contradictory situation can lead to political anger levelled at a regime of masters. It can involve the demand of material equality and the reorganisation of politics and economics as something that would guarantee full, mutual recognition for all humans. The concept of recognition in the modern world then contains this radical and impossible desire. As capitalism spreads historically across states, this desire, and the indignation of the impoverished against global inequality, spreads with it.

\section{Recognition Going Global}

On the reading given so far, two forms of freedom are affirmed within a concept of recognition. The first is the idea of republican citizenship, that is, the freedom of citizens who are affirmed communally as equal members of a political community. This mode of human understanding stretches across the ancient world of Greek and Roman republics and is reimagined in modernity in a variety of liberal, socialist and social-democratic guises. The second is the

\footnotetext{
${ }^{5}$ See generally: Marx 1994; Marx 1988.
} 
modern idea contained with commercial or capitalist societies in which individual freedom is expressed via inter-subjective market exchange as the mutual satisfaction of needs.

Yet within capitalist economies any trend towards the impoverishment of large parts of the population and the rise of high levels of economic inequality across societies presents a sphere of unfreedom. Poverty and inequality are the economic modes of unfreedom in which parts of the population are denied full mutual recognition. In this a class of individuals are forced into a life in which they are denied the opportunity for the full realisation of freedom, either as agents who participate equally in the political realm, or as agents who realise their particular needs and desires via the market.

In this respect, under modern conditions of capitalism, there sits a contradiction and a gap between, the ideal of freedom in both political and economic senses, and, the realities of unfreedom occurring as a consequence of impoverishment and inequality. One response to rampart inequality is an attitude of indignation, an understanding that the state of affairs is wrong. A possible consequence are ongoing struggles for recognition which attempt to negate this condition of unfreedom and to make 'real' or 'actual' whatever is posited as a modern 'rational' ideal of freedom. In response to differing concrete conditions of unfreedom within differing regions of global capitalism, these responses and claims for recognition may take differing forms - from open violence, revolt, and to non-violent occupation. The contemporary forms of such struggles for recognition are plural and perhaps chaotic, they cross differing spaces and territories and manifest in differing forms of antagonism and social conflict. Contemporary demands of recognition combine claims of identity, political inclusion and economic equality. Hence, recognition, as a philosophical and political concept always contains within it the demands for economic redistribution and economic justice.

This dual account helps us to reconsider the relationship between the concept of recognition and the international. Such an approach broadens also the ways in which Hegel's 
concept of recognition can be seen to be relevant to an understanding of international affairs. Within the Philosophy of Right, Hegel uses a political conception of recognition to offer an account of inter-state relations in which the focus is upon questions of war and violence and the shaping of international legal personality through the acknowledgement of statehood by other states. ${ }^{6}$ On this view the state is a status, it gains the status of international legal personality in a manner that bears some similarity to the recognition of citizenship within ancient and modern republics (Hegel 1991: §331). In some respects this manner of inter-state recognition is merely formal, as a state which has military power and wealth is perhaps less in need of acknowledgement than its weaker neighbours. Yet, in other respects the formal nonrecognition of the status of statehood is very significant. The denial of recognition of the independence of a political community has played a key role in forms of domination that have characterised international relations in modernity.

In a manner similar to the non-recognition of the individual, the refusal of republican equality, and the portrayal of an individual as subservient, non-human or as slave, inter-state non-recognition has extended throughout modern international relations and international law via the history of colonialism, international hegemony and empire. Mastery and slavery, freedom and unfreedom within the international have been shaped by modern theories of race and cultural superiority. In the $19^{\text {th }}$ century intellectual figures like Hegel could thus adopt something of a hypocritical position in relation to the concept of recognition. On the one hand Hegel was a supporter of a modern republican ideal in which all citizens of European states should be granted civic and economic freedom and formal equality. On the other hand, Hegel stands within a tradition of European thinkers adopting an 'orientalist' mind-set who viewed a number of peoples around the world as so uncivilised as to not deserve the recognition of statehood. Consider Hegel's comment in the Philosophy of Right:

\footnotetext{
${ }^{6}$ For a more detailed account of this see: Kochi 2009.
} 
(R)ecognition requires a guarantee that a state will likewise recognise those other states which are supposed to recognise it, i.e. that it will respect their independence; accordingly, these other states cannot be indifferent to its internal affairs. - In the case of a nomadic people, for example, or any people at a low level of culture, the question arises of how far this people can be regarded as a state. (Hegel 1991:§ 331)

There is quite a lot that can be drawn out from this, though here two ideas are perhaps most relevant. In one sense, while Hegel's Eurocentric and somewhat racist comments strike the contemporary ear as unfortunate and morally wrong, they do point to something important within our understanding of modern international relations and international law. For Hegel, the form of republican equality and liberty that comes from mutual recognition is not a given. Rather, it is the outcome of very often violent, political struggles for recognition in which the status of citizenship and communal/state independence is often won or lost via fighting. The idea of the violent struggle for recognition by the slave thus has relevance to understanding the sphere of global anti-colonial struggles in the $19^{\text {th }}$ and $20^{\text {th }}$ centuries, a point taken up and developed by Frantz Fanon.

In another sense, the hypocrisy of Hegel's position can be seen to continue today not simply at a level of global racial politics, but in the ideological non-recognition of particular states, political formations and forms of life. We can think of how in the $20^{\text {th }}$ and $21^{\text {st }}$ centuries the dominant, global hegemonic power, the USA, has refused to recognise the independence of a number of political regimes and through both open and covert violence has set out to destroy their independence. One example is the USA's war against Vietnam in 1960's and 1970's. Another is the USA's war against and occupation of Iraq (2003-) and against the Islamic State of Iraq and Syria (ISIS) (2014-). In each of these cases the question of nonrecognition of status is linked to the way in which an international hegemon attempts to assert power and control over a global capitalist world system. ${ }^{7}$ In this respect, violent international

\footnotetext{
${ }^{7}$ On the role of economic, military and political/cultural hegemony within the 'modern capitalist world system' see: Wallerstein 2011.
} 
struggles for recognition and status between political groupings which take place as war, occur also as attempts by competing political elites to arrest control over the economic ordering of societies, domestically, regionally and internationally. Identity and status recognition claims here are deeply linked to attempts to control the process of global capitalist accumulation and implement differing ideological visions of economic justice.

Struggles for recognition within the international, especially in the $20^{\text {th }}$ and $21^{\text {st }}$ centuries cannot be divorced from conflicts between rival political groupings over the nature of domestic and global questions of economic justice. While commonly these conflicts have taken place through the juridical and political frame of statehood, self-determination, national liberation and nationalism, these conflicts arise also across juridical and political boundaries. Here Hegel's conception of the indignity of economic alienation and impoverishment under the conditions of modern capitalism remain relevant, as are his concerns about the demands of the 'rabble'.

Hegel's concept of the 'rabble' is interesting, the rabble is not a fully conscious economic class which adopts some form of transformative historical and political agency as in Marx. Rather, it appears more as a sense of disorganised bursts of outrage and anger against an economic and political system which offers the promise of economic freedom and satisfaction but grants only impoverishment, the denial of dignity and feeling of indignation. The rabble represents the failure of political and economic recognition under modern capitalism. Further, the concept of the rabble expresses the contradictory demands of wanting both, full satisfaction from an economic system, and the negation of the same economic system. The rabble responds to a distinct lack of recognition with its often contradictory demands via chaotic forms of protest and riot.

There is something of a revival of Hegel's concept of the rabble amongst aspects of contemporary 'post-Marxist' political theory which celebrate the non-totalising, multiform, 
chaotic and multipolar sense of this form of political (dis)organisation. One example is Hardt and Negri's concept of the 'multitude' which attempts to describe the contemporary forms of inoperative spurts of protest, riot and political groupings which came to prominence in North America and Western Europe by way of the anti-globalisation protests in the 1990's. ${ }^{8}$ Similarity can be found also within current forms of anti-capitalist protests, either in terms of the 'Occupy' protests of early $21^{\text {st }}$ century, or in the forms of protest that constituted the 'Arab Spring' which combined protests against impoverishment with the denouncing of authoritarian regimes.

In this light, we can consider the last decade of the $20^{\text {th }}$ century and the initial decades of the $21^{\text {st }}$ to involve a set of diffuse, sporadic and largely uncoordinated (or only thinly coordinated) bursts of protest, riot, and revolt popping up across the globe, all of which share a number of similar sentiments. Each of these situations can be considered in terms of recognition claims which express a feeling of indignation against the injustices of modern global capitalism and which demand some form of economic justice. The exact content of what this form of 'economic justice' might be is in no way uniform or universal. However, something that perhaps is shared amongst these contemporary 'rabbles' or 'multitudes' scattered and stretched across the globe, is the feeling of indignation, the feeling of not being recognised and not being affirmed by a political and economic system that robs people of their dignity through wage-exploitation, alienation and impoverishment. What remains clear in these protests, riots and revolts across the globe is that these are struggles for recognition in which the demand for economic justice is deeply linked to demands of status and identity.

\footnotetext{
${ }^{8}$ Hardt and Negri would generally deny this Hegelian aspect of their thought, and instead trace the concept of the 'multitude' to Machiavelli and Spinoza. See also: Ruda 2013.
} 


\section{Bibliography}

Anderson, P. (1996) Passages from Antiquity to Feudalism, London: Verso.

Arendt, H. (1998) The Human Condition, Chicago: University of Chicago Press.

Aristotle, (2001) The Basic Works of Aristotle, R. McKeon (ed.), New York: Modern Library.

Avineri, S. (1972) Hegel's Theory of the Modern State, Cambridge: Cambridge University Press.

Brenner, R. (1977) "The Origins of Capitalist Development: A Critique of Neo-Smithian Marxism”, New Left Review, no. 104, pp. 25-92.

Brunt, P.A. (1971) Social Conflicts in the Roman Republic, New York: Norton \& Co.

Buck-Morss, S. (2000) “Hegel and Haiti”, Critical Inquiry, 26(4), pp. 821-865.

Fanon, F. (1963) The Wretched of the Earth, C. Farrington (tr.), New York: Grove Weidenfeld. Finlay, M.I. (1999) The Ancient Economy, Berkeley: University of California Press.

Forrest, W.G. (1966) The Emergence of Greek Democracy, London: Weidenfeld and Nicolson.

Fraser, N. and Honneth, A. (2003) Redistribution or Recognition, London: Verso.

Habermas, J. (1984) The Theory of Communicative Action Vol 1., T.McCarthy (tr.) Boston: Beacon Press.

Hardt H. and Negri, A. (2000) Empire, Cambridge, Mass.: Harvard University Press.

Hegel, G.W.F. (1991) Elements of the Philosophy of Right, A.W. Wood (ed.) H.B. Nisbet (tr.) Cambridge: Cambridge University Press.

Hegel, G.W.F (1977) Phenomenology of Spirit, A.V. Miller (tr.) Oxford: Oxford University Press.

Hilton, R. (1973) Bondmen Made Free, London: Methuen \& Co.

Kochi, T. The Other's War: Recognition and the Violence of Ethics, Abingdon: Birkbeck Law Press, 2009. 
Kojève, A. (1980) Introduction to the Reading of Hegel, J.H. Nichols (tr.) Ithaca, N.Y: Cornell University Press.

Mann, M. (1986) The Sources of Social Power, Vol. 1, Cambridge: CUP.

Marx, K. (1994) ‘Toward a Critique of Hegel's Philosophy of Right: Introduction' L.D. Easton and K.H. Guddat (trs.) in L.H. Simon (ed.) Karl Marx Selected Writings, Indianapolis: Hacket Publishing.

Marx, K. (1988) Economic and Philosophic Manuscripts of 1844, M. Milligan (tr.) Prometheus Books: Amherst.

Marx, K. and Engels, F. (1969) The Communist Manifesto, S. Moore (tr.) Harmondsworth: Penguin.

McBride, C. (2013) Recognition, Cambridge: Polity.

Nancy, J. (2000) The Restlessness of the Negative, Minneapolis: University of Minnesota Press.

Nietzsche, F. (2000) Basic Writings of Nietzsche, W. Kaufman (tr.) New York: Modern Library.

Pocock, J. (2003) The Machiavellian Moment: Florentine Political Thought and the Atlantic Republican Tradition, Princeton: Princeton UP.

Riedel, M. (1984) Between Tradition and Revolution: The Hegelian Transformation of Political Philosophy, W. Wright (tr.) Cambridge: Cambridge University Press.

Ritter, J. (1982) Hegel and the French Revolution: Essays on the Philosophy of Right, R.D. Winfield (tr.) Cambridge Mass.: MIT Press.

Ruda, F. (2013) Hegel's Rabble, London: Bloomsbury.

Said, E. (1978) Orientalism, London: Routledge.

Smith, A. (1999) The Wealth of Nations, A. Skinner (ed.), London: Penguin.

Wallerstein, I. (2011) The Modern World System Vol. 1., Berkeley: University of California Press. 